\title{
PENDIDIKAN ISLAM ALTERNATIF: Studi pada SD Plus Islamic Center Manado
}

\author{
Ta'rif \\ Peneliti Puslitbang Pendidikan Agama Dan Keagamaan \\ Badan Litbang dan Diklat Kementerian Agama RI \\ Jl. MH Thamrin No. 06 Jakarta Pusat \\ Email: fajarhm@yahoo.co.id
}

\begin{abstract}
This paper examines the process of how alternative Islamic education arose, its strategy, and expectation in the future. This research uses qualitative approach in the SD Plus Islamic Center Manado location. Among the discoveries, the Moslem communities have chosen the SD Plus Islamic Center as an alternative Islamic education, based on the following reasons: initially to protect their children from ideological affections from other religions, to combine the science and technology curriculum (IPTEK) and religious teachings (IMTAK) by integrating Islamic values in the teaching process (KBM), and to participate in the development of the global era.
\end{abstract}

Keyword: alternative Islamic education, strategies and implementation.

\begin{abstract}
Abstrak
Tulisan ini akan mengkaji tentang bagaimana latar belakang munculnya pendidikan agama Islam alternatif, strategi dan model penyelenggaraan pendidikan Islam altenatifyang diharapkan di masa yang akan datang. Penelitian ini menggunakan pendekatan kualitatif dengan mengambil lokasi di SD Plus Islamic Center Manado. Di antara hasil temuannya adalah bahwa pilihan masyarakat muslim yang menjadikan SD Plus Islamic Center sebagai pendidikan agama Islam alternatif, karena didasari beberapa faktor yaitu: pertama, sebagai bentuk quaranti terhadap pembinaan ideologi/akidah sekaligus menawarkan pendidikan yang berkualitas. Kedua: mengembangkan kurikulum berbasis agama (IMTAK) dan umum (IPTEK) dengan mengintegrasikan Nilai-Nilai Keislaman dalam setiap proses setiap Kegiatan Belajar Mengajar (KBM), ketiga dapat berkompetisi dalam memasuki perkembangan dunia yang mengglobal.
\end{abstract}

Kata Kunci: Pendidikan Islam alternatif, strategi dan model penyelenggaraan

\section{PENDAHULUAN}

Pendidikan merupakan kebutuhan sepanjang hayat long life education atau dalam terminologi Islamya adalah minal mahdi ilal lahdi. Setiap manusia membutuhkan pendidikan, sampai kapan dan dimanapun ia berada. Pendidikan sangat penting artinya, sebab tanpa pendidikan manusia akan sulit berkembang dan bahkan akan terbelakang. Dengan demikian pendidikan harus betulbetul diarahkan untuk menghasilkan manusia yang berkualitas dalam arti menguasai Iptek dan mampu bersaing, berbudi pekerti luhur serta memiliki akhlak mulia.

Dalam UU Sisdiknas No. 20 Tahun 2003 disebutkan bahwa tujuan dari pendidikan nasional diharapkan adalah berkembangnya

Naskah diterima 27 September 2013. Revisi pertama, 22 Oktober 2013. Revisi kedua, 10 November 2013 dan revisi terahir 3 Desember 2013. 
potensi peserta didik agar menjadi manusia yang beriman dan bertakwa kepada Tuhan Yang Maha Esa, berakhlak mulia, sehat, berilmu, cakap, kreatif, mandiri, dan menjadi warga negara yang demokratis serta bertanggung jawab. Pendidikan harus mampu mempersiapkan warga negara agar dapat berperan aktif dalam seluruh lapangan kehidupan, cerdas intelektual, kreatif, terampil, jujur, berdisiplin dan bermoral tinggi, toleran dan demokratis.

Pendidikan merupakan investasi penting dalam menghadapi masa depan dunia secara global. Untuk itu, pendidikan semestinya dapat menyiapkan generasi muda abad ke-21 yang unggul, berdaya saing tinggi dan mampu bekerjasama guna mencapai kemakmuran bagi setiap negara dan dunia.

Pendidikan yang menghasilkan output yang baik dan mampu bersaing dengan kebutuhan zaman merupakan harapan semua masyarakat, karenanya lembaga pendidikan mau tidak mau harus memiliki nilai daya saing. Kompetisi dunia pendidikan tidak bisa terelakan, hal ini menuntut adanya perbaikan mutu. Keberadaan pendidikan pada dasarnya akan tetap bertahan dan diminati oleh masyarakat apabila pendidikan tersebut dapat memenuhi eskpektasi dan dambahan masyarakat sebagai pengguna pendidikan

Di Indonesia dikenal berbagai bentuk dan jenis pendidikan Islam, seperti Pondok Pesantren, Madrasah, Sekolah Umum bercirikan Islam, sebagaimana juga dikatakan Karel Steenbrink bahwa keberadaan pendidikan Islam di Indonesia cukup variatif. Ia mengkategori pendidikan tersebut dalam tiga jenis, yaitu pendidikan Islam yang berbasis pada pondok pesentren, madrasah dan sekolah. Variasi lembaga pendidikan Islam tersebut menjadi pilihan tersendiri bagi masyarakat muslim. Sebagian besar masyarakat muslim banyak memilih jalur pendidikan pesantren dan madrasah, sedangkan sebagian ada pula yang memilih lembaga pendidikan sekolah Islam.
Seiring dengan perubahan yang terjadi, lembaga pendidikan Islam terus melakukan perubahan dalam berbagai bidang, hal ini sebagai upaya menghadapi berbagai tantangan dan peluangyang mengitarinya.Tantanganbagi lembaga pendidikan Islam semakin komplek yaitu tidak hanya sekedar mentransmisikan ilmu-ilmu kepada siswa, tetapi tidak kurang pentingnya mengembangkan pendidikan Islam yang lebih berkualitas bagi anak-anak bangsa sehingga memiliki keunggulan kompetitif di era globalisasi kini dan mendatang. ${ }^{1}$

Hadirnya lembaga pendidikan Islam yang menjadi harapan masyarakat muslim merupakan sebuah kemestian. Di beberapa kota di Indonesia telah muncul fenomema baru dalam dunia pendidikan Islam yang menjadi alternatif/pilihan masyarakat muslim, yakni dengan berdirinya sekolah Islam Unggulan -sebut saja Al-Azhar, Al-Izhar, Muthahari, MAN Insan Cendekia dan beberapa Sekolah Islam Terpadu. Sekolah ini tumbuh sejalan dengan terbentuknya masyarakat Muslim Kelas menengah perkotaan. Di Kota Manado Sulawesi Utara, trend sekolah Islam ini bisa di lihat antara lain dengan berdirinya Lembaga pendidikan SD Plus Islamic Center yang didirikan Yayasan Karya Islamiyah.

Tulisan ini merupakan hasil laporan penelitian Penyelenggaranan Pendidikan Agama Alternatif yang dilakukan di SD Plus Islamic Centre Manado. Pemilihan Sekolah ini karena lembaga pendidikan ini memiliki kekhususan dan keunggulan tersendiri, baik dari kelembagaan, visi dan misi, manajemen, sarana dan prasarana yang dibangun serta lingkungan budaya sekolah yang lebih Islami. Berbeda dengan sekolah publik yang ada umumnya lebih bernuansa budaya Kristen, karena memang mayoritas masyarakatnya beragama Kristen. Dalam tulisan ini difokuskan tentang bagaimana latar belakang munculnya

1 Azyumardi Azra. Pendidikan Islam Indonesia dan Tantangan Globalisasi: Perspektif Sosia-Historis, dalam dalam kata Pengantar Buku Jajat Burhanuddin dkk. 2006. Mencetak Muslim Modern: Peta Pendidikan Islam Indonesia. Jakarta: RajaGrafindo Persada, h. 1 
pendidikan agama Islam alternatif, bagaimana strategi yang dikembangkan dalam upaya meningkatkan pendidikan agama, serta bagaimana model penyelenggaraan pendidikan Islam altenatif yang diharapkan di masa yang akan datang.

\section{KERANGKA KONSEPTUAL}

\section{Pendidikan Agama Alternatif}

Saat ini telah berkembang di masyarakat jenis atau bentuk pendidikan yang memiliki nilai keunggulan-keunggulan baik dari segi manajemen, metode pembelajaran, kurikulum dan pendekatan lainnya yang memilki nilai kompetitif. Istilah jenis dan atau bentuk pendidikan ini, ada yang menyebut sekolah plus, sekolah unggulan, sekolah alternatif, dan sejenisnya. Terminologi ini berkembang dan dikembangkan pada awal dekade 1990an dengan semakin banyaknya bermunculan sekolah-sekolah unggul di berbagai daerah. Munculnya pendidikan alternatif dapat disebabkan faktor kultural, sosial maupun keagamaan. Terminologi lain yang lazim digunakan untuk penyebutan unggulan adalah sekolah plus, seperti sekolah Muthahari Bandung, al-Azhar, Al-Izhar, Sekolah Taruna Nusantara, dan lain-lain.

Istilah pendidikan alternatif sendiri merupakan istilah generik dari berbagai program pendidikan yang dilakukan dengan cara berbeda dengan cara konvensional/ tradisional. Secara umum pendidikan alternatif memiliki persamaan; pendekatan bersifat individual, memberi perhatian basar kepada peserta didik, orangtua/keluarga, pendidik dan dikembangkan berdasarkan minat dan pengalaman.

Menurut Yusuf Hadi Miarso ${ }^{2}$ Pendidikan alternatif adalah istilah dari berbagai program pendidikan yang dilakukan dengan

2 Yusuf Hadi Miarso. 1999. Pendidikan Alternatif Sebuah Agenda Reformasi. Jakarta: Jurusan Teknologi Pendidikan UNJ, h. 1 cara berbeda dari cara tradisional. Tipologi pendidikan alternatif dapat mengembangkan paradigma baru yang dianggap dapat dijadikan jalan keluar sebagai lawan dari tipologi belajar konvensional. Pendidikan alternatif membangun pembelajaran yang faktual, konseptual, dan konstektual.Sebagaiamnayang dijelaskan oleh Johar, pendidikan alternatif adalah Pendidikan yang berorientasi kepada proses pendidikan yang mengembangkan kompetensi: 1) metodologi, 2) konseptualisasi, 3) pemahaman konsep, 4) aplikasi, dan 5) nilai (value). ${ }^{3}$

Selanjutnya mengenai bentuk-bentuk pendidikan alternatif, menurut Jery Mintz yang dikutip oleh Miarso ${ }^{4}$, Pendidikan alternatif dapat dikategorikan dalam empat bentuk pengorganisasian, yaitu: a) Sekolah Publik Pilihan (public choice); contoh: SMP Terbuka, SMU Terbuka, Universitas Terbuka. Sekolah/ Lembaga, b) Pendidikan Publik untuk Siswa Bermasalah (student at risk), contoh: tinggal kelas karena lambat belajar, nakal, korban penyalahgunaan narkoba, dll, c) Sekolah/ Lembaga Pendidikan Swasta (independent); contoh program pendidikan bercirikan agama seperti pesantren \& sekolah Minggu, pendidikan usia dini seperti penitipan anak, kelompok bermain dll, dan d) pendidikan di rumah (home schooling).

Pemerintah memberi peluang kepada masyarakat untuk melembagakan pendidikan dengan kriterium yang mereka ciptakan, namun tetap berada dalam garis kebijakan nasional pendidikan. Oleh Karena itu pendidikan alternatif merupakan pendidikan yang diorganisasikan secara khas versi penyelenggara melalui pola pendidikan yang kurikulumnya bersifat desentralistik, dimana anak didik dapat memilih materi pembelajaran sesuai dengan minatnya, atau materi yang sesuai dengan kebutuhan dan lingkungan anak

${ }^{3}$ Johar. 2008. Kurikulum yang mencerdaskan. Visi 2030 dan Pendidikan Alternatif. Jakarta: Penerbit Buku Kompas, h. 149

${ }^{4}$ Yusuf Hadi Miarso, Loc. Cit. 
didik, biayanya murah, sederhana, luwes dan menempatkan anak sebagai subjek. ${ }^{5}$

Penggunaan istilah plus, alternatif atau unggulan memiliki makna tersendiri yaitu secara operasional dalam penyelenggaraan pendidikannya memiliki nilai plus/tambah atau keunggulan tertentu yang mungkin tidak dimiliki oleh sekolah sekolah lain. Keunggulan tersebut boleh jadi terwujud pada kurikulum pendidikannya, visi pendidikannya, dan lainlain. Dapat dipastikkan bahwa salah satu nilai plus Sekolah Islam Unggulan adalah kurikulum pendidikan agamanya yang relatif lebih banyak dibandingkan dengan sekolahsekolah umum lainnya.

Konsep Pendidikan agama dapat difahami sebagai "lembaga" yang menyelenggarakan pendidikan agama plus, tetapi juga dapat difahami sebagai bobot mata pelajaran pendidikan agama Islam yang didisain sesuai dengan visi dan misi lembaga masyarakat pendukungnya. Pengertian Pendidikan agama menurut Peraturan pemerintah No 55 tentang Pendidikan Agama dan Keagamaan Tahun 2007 Pasal 1 adalah pendidikan yang memberikan pengetahuan dan membentuk sikap, kepribadian dan ketrampilan peserta didik dalam mengamalkan ajaran agamanya, yang dilaksanakan sekurang-kurangnya melalui mata pelajaran/kuliah pada semua jalur, jenjang dan jenis pendidikan. ${ }^{6}$

Dengan demikian pendidikan agama dapat dimaknai bahwa pendidikan agama diharapkan dapat mendorong peserta didik untuk taat menjalankan ajaran agamanya dalam kehidupan sehari-hari dan menjadikan agama sebagai landasan etika dan moral dalam kehidupan pribadi, berkeluarga, bermasyarakat, berbangsa dan bernegara.

Selanjutnya pendidikan agama dapat dipahami; pertama, sebagai proses (tanggung

${ }^{5}$ Bunga Rampai kajian Pendidikan Nasional. 1998. Pendidikan Alternatif sebagai proses pemanusiaan. Jakarta: Depdiknas, h. 142

${ }^{6}$ Peraturan pemerintah No 55 Tahun 2007 tentang Pendidikan Agama dan Pendidikan Keagamaan jawab keluarga, sekolah dan masyarakat; UU Sisdiknas No. 20 Tahun 2003 pasal 46 ayat (1). Kedua, sebagai lembaga/satuan pendidikan yang menempatkan pendidikan agama sebagai dasar visi dan misinya (education for religion). Ketiga, sebagai mata pelajaran dari kurikulum yang diajarkan pada jenjang/satuan pendidikan (subject matter).

Dengan demikian yang dimaksud dengan pendidikan agama alternatif dalam tulisan ini adalah pilihan-pilihan layanan pendidikan agama pada sekolah umum berciri khas Islam yang ada dalam masyarakat dengan sistem pendidikan Islam yang integratif, terpadu dan berkesinambungan. Pendidikan agama alternatif juga dimaknai sebagai lembaga pendidikan yang memiliki keunggulan dalam penanaman nilai-nilai dan ajaran agama sebagai respon terhadap sistem pendidikan agama yang ada karena dianggap belum memenuhi harapan mereka. Pendidikan unggulan merupakan istilah yang muncul dalam dunia pendidikan

\section{METODOLOGI}

Penelitian ini merupakan penelitian kualitatif, melalui pendekatan ini peneliti mencoba memperoleh gambaran yang jelas tentang keberadaan SD Plus Islamic Center Manado sebagai menjadi lembaga pendidikan Islam yang menjadi alternatif dan diperhitungkan bagi masyarakat muslim Manado..

Subyek penelitian ini adalah lembaga pendidikan pada SD Plus Islamic Centre Manado Sulawesi Utara. Sementera respondennya adalah Kepala Sekolah, Guru, Orangtua siswa, Murid, Pejabat Kemenag. Sebagai penelitian kualitiatif, peneliti adalah sebagai key instrumen, dengan bantuan pedoman wawancara dan studi dokumen, peneliti merekam, mencatat, mengkaji, melakukan check dan recheck, mengklasifikasi, serta mengembangkan dan mengabstraksi data dan informasi yang diperoleh dari informan. 
Data-data yang dihimpun melalui wawancara mendalam, daftar isian dan studi kepustakaan diolah dan dirumuskan menjadi laporan penelitian. Informan penelitian ini terdiri dari unsur-unsur sebagai berikut: pimpinan lembaga, kepala sekolah, pendidik, orang tua dan peserta didik.

\section{HASIL DAN PEMBAHASAN}

\section{SD Plus Islamic Centre; Merespon Kegelisahan Ummat}

SD Plus Islamic Center terletak di tengah-tengah Kota Manado, di sekitarnya terdapat beberapa perkantoran pemerintah daerah maupun swasta, SD ini juga berada di lingkungan Masjid Agung Manado yang menjadi kebanggaan dan pusat kegiatan keagamaan ummat Islam Manado. Dengan demikian posisi SD Plus Islamic Centre ini sangatlah strategis dan menjadi daya tarik tersendiri. Selain itu, tidak jauh dari sekolah ini terdapat pula sekolah-sekolah favorit dan unggulan seperti Don Bosco, Santa Ursula, YKPM yang dimiliki agama Nasrani, dengan demikian atmosfir kompetisi dalam meningkatkan mutu lembaga pendidikan sangat nampak dan menjadi tantangan tersendiri bagi lembaga.

SD Plus Islamic Centre didirikan oleh beberapa tokoh muslim Manado seperti Drs. H. Abdullah Mokoginta (mantan Gubernur Sulawesi Utara), Muhammad Arsyad Daud SH, Drs. H. Djainuddin Ahmad (Mantan Kepala Kanwil Depag Propinsi Sulawesi Utara), Abdul Kadir Bajeber, SH , Udin T. Lanco dan tokoh-tokoh lainnya. Diantara beberapa hal yang melatari berdirinya SD Plus Islamic Centre dapat dikategorikan pada dua aspek, yaitu faktor internal dan eksternal. Faktor internal diantaranya pertama ; Sekolah Islam yang menjadi andalan dan pilihan di Kota Manado belum menjadi pilihan bagi kaum kalangan ummat Islam, walaupun terdapat lembaga pendidikan Islam (sebut saja SD Yapim, SD Muhammadiyah dan SD Al-Khairat) masih belum mampu menarik perhatian dan menjadi pilihan masyarakat muslimin di Kota Manado pada umumnya, Kedua, masyarakat muslim sendiri ada sebagian anaknya di sekolahkan di sekolah-sekolah non muslim favorit. Akibatnya banyak diantara mereka tidak mendapatkan pelajaran agama Islam bahkan lingkungan yang Islami, kekhawatiran ini cukup menjadi perhatian masyarakat muslim. Ketiga, adanya kebutuhan/kesadaran masyarakat terhadap lembaga pendidikan yang tidak hanya mendapatkan pengetahuan umum tetapi juga mendapatkan pendidikan agama yang langsung di praktekkan dalam kehidupan sehari-hari.

Sementara itu, faktor eksternal; pertama, lahirnya Undang Undang tentang Otonomi daerah yang secara tidak langsung membawa dampak positif maupun negatif. Dampak negatifnya adalah kurang menguntungkan kebijakan-kebijakan pemerintah daerah terhadap kaum minoritas baik secara politik maupun agama. kedua, lahirnya UndangUndang Sisdiknas nomor 20 tahun 2003 yang munculkan pro dan kontra saat disahkan di DPR RI. Ketiga, munculnya pemahamanpemahamaan di luar Islam/agama lain yang merasuki ummat Islam di Kota Manado.

Keinginanmembentuklembagapendidikan Islam yang bermutu, sudah menjadi dambaan masyarakat muslim Manado, keinginan ini telah dirintis sejak tahun ajaran 2000/2001 yaitu adanya keinginan membentuk suatu lembaga Sekolah (terutama SD) yang dapat diandalkan dan menjadi pilihan ummat Islam, selain itu lembaga ini nantinya diharapkan dapat menyiapkan generasi ummat Islam yang lebih baik. Keinginan tersebut semakin kuat tatkala akan diundangkannya UndangUndang Nomor 20 Tahun 2003 tentang Sistem Pendidikan Nasional, dimana saat lahirnya tersebut terdapat pro dan kontra di kalangan masyarakat saat disahkan. Suasana pro kontra secara tidak langsung membawa efek kurang menguntungkan di daerah-daerah, apalagi secara kuantitas (secara politik, jumlah 
penganut maupun lainnya) jumlah ummat Islam minoritas.

Usaha untuk merespon keinginan awal diatas, beberapa pengurus yayasan dan masyarakat Islam pada umumnya, tentang perlunya mendirikan lembaga pendidikan dasar yang berkualitas dan kompetitif. Tujuan lainnya adalah dalam rangka menghindari ketidakharmonisan secara horizontal dengan tetap memelihara lestarinya persatuan dan kesatuan bangsa terutama dalam memelihara mantapnya kerukunan hidup antar beragama.

Melalui berbagai pertemuan pembahasan, baik secara formal maupun non formal di kalangan pengurus Yayasan maupun masyarakat muslim Manado. Akhirnya pada awal tahun ajaran 2004/2005, resmi dibuka lembaga SD Plus Islamic Center dengan Surat Keputusan Yayasan nomor 05/2004 tanggal 146-2004, dengan menampung siswa sebanyak 40 murid. Sementara itu keputusan pengurus Yayasan Karya Islamiah dengan No.: 06/2004, tanggal 17 Juni 2004. Untuk menjalankan organisasi lembaga SD ini telah diangkat beberapa personil yaitu: Dra. Rahmah Apiya Agustiaty sebagai Kepala Sekolah, sedangkan sebagai Guru Kelas adalah Heny Nining Gani, S.Ag, Yuniaty Tadete, S.Pd.I, dan Fitri Muarif sebagai Tata Usaha Sekolah.

Sekolah Dasar Plus Islamic Center memiliki visi: menjadikan sekolah Dasar yang handal dan bermutu tinggi. Untuk merealisasaikan visi tersebut tersusun beberapa misi antara lain; 1) meningkatkan profesional guru, dan karyawan dalam mengembang amanah di sekolah sesuai dengan tugas dan wewenangnya. 2) menjalin hubungan intensif yang saling menguntungkan dengan masyarakat, pemerintah, LSM, dan sekolah negeri/swasta lainnya, 3) mengikutsertakan orangtua dan masyarakat yang peduli pendidikan dalam sistem pengelolaan sekolah. Sementara motto sekolah ini adalah: SD Plus Islamic Center membina generasi muda yang berkualitas dan Islami menuju masa depan yang cemerlang.
Secara khusus tujuan pendidikan SD Plus Islamic Centre adalah menyelenggarakan pendidikan dasar Islami yang mampu membentuk karakter anak sehingga memiliki pengetahuan, sikap dan perilaku sesuai dengan kebutuhan zaman dan tuntutan anak dalam Islam. Untuk mewujudkan tujuan diatas, ada penerapan nilai-nilai yang harus dikembangkan, yaitu: a) Rabbaniyah: meluruskan niat dan menjaga keikhlasan amal; b) Amanah: menunaikan tugas dengan penuh rasa tanggungjawab; c) Ukhuwah: menjalin kerjasama dalam persaudaraan secara efektif; d) Khidmah; mengedepankan bantuan dan pelayanaan; dan e) Dakwah: menyebarkan kebaikan dan mencegah kemungkaran

Selain penerapan nilai-nilai yang dikembangkan, di SD Plus Islamic Center juga menerapkan Budaya yang dikembangkan dengan memakai Istilah $5 \mathrm{R}$ :

a. Ringkas (R1) = simple, tidak banyak menggunakan tempat;

b. $\quad$ Resik (R2) = bersih;

c. Rapih (R3) = baik - teratur - apik;

d. Rajin (R4) = suka dan sungguh-sungguh bekerja/belajar;

e. $\quad$ Rawat (R5) = pelihara - urus - jaga.

Keunggulan sistem pendidikan SD Plus Islamic Centre, diharapkan anak-anak mendapatkan pendidikan yang terpadu antara pendidikan umum dan agama yang antisipatif terhadap perkembangan zaman. Melindungi anak dari pengaruh pergaulan di luar sekolah. Karena pendidikan sistem fullday anak lebih lama di sekolah, lebih terarah dan terencana. Bagi pasangan suami istri yang bekerja tidak hawatir pentang pendidikan dan perkembangan kepribadin putra putrinya, karena dididik oleh tenaga kependidikan yang tertlatih dan profesional. Perkembangan bakat dan minat dan kecerdasan anak dapat terpantau sejak dini dan sisi-sisi aktivitas 
anak di rumah dan sekolah terpantau melalui mekanisme kontrol guru.

Penggunaan istilah plus pada sekolah unggulan ini memiliki makna tersendiri yaitu secara operasional dalam penyelenggaraan pendidikannya memiliki nilai plus/tambah atau keunggulan tertentu yang mungkin tidak dimilki oleh sekolah sekolah lain. Keunggulan tersebut boleh jadi terwujud pada kurikulum pendidikannya, visi pendidikannya, dan lainlain. Dapat dipastikkan bahwa salah satu nilai plus Sekolah Islam Unggulan adalah kurikulum pendidikan agamanya yang relatif lebih banyak dibandingkan dengan sekolahsekolah umum lainnya.

Dari segi sosial ekonomi orang tua siswa, mereka ini tergolong kelas menengah, sebagian besar adalah para pegawai negeri maupun swasta yang bekerja di lingkungan sekitar Kota Manado. Sebagian lagi siswa adalah pindahan dari daerah lain, karena anakanak mereka mengikuti orangtuanya bekerja di Manado, sehingga orangtua menginginkan sekolah ke lembaga pendidikan yang ada nilai plusnya. Dari banyaknyanya siswa yang pindahan ini, sekolah ini seringkali mendapat label sekolah transit. Salah satu yang menjadi alasan mengapa pihak sekolah menerima mereka, karena faktor orangtua menginginkan sekolah yang ada nilai plusnya terutama dalam pendidikan agama. Sebagian besar orang tua berharap anak-anaknya ingin mendapatkan pendidikan agama dan sekaligus mendapatkan pendidikan umum.

Menurut Kepala Sekolah, model pendidikan tradisional dalam bentuk madrasah dan pesantren sudah banyak yang menggarap. Sementara itu, di perkotaan besar seperti Manado, semakin banyak muslim yang ingin menyekolahkan anak-anak mereka ke sekolah favorit, yang umumnya dimiliki kelompok non-muslim. Atas dasar itulah konsep sekolah Islam modern lahir, dalam kerangka itulah sekolah SD Islamic Centre didirikan.

\section{Model Kurikulum yang ditawarkan: Kurikulum Integratif}

Untuk menjamin pencapaian keunggulan itu, SD Plus memadukan kurikulum Diknas dan Kurikulum Yayasan. Penerapan nilainilai Keislaman dalam kehidupan sehari-hari dikemas sedemikian rupa sehingga siswa-siswa tidak merasa jenuh. Siswa-siswa memulai pelajarannya dengan membaca muraja'ah dan kemudian do'a yang dibimbing masingmasing guru kelas. Demikian juga dengan praktik shalat dan pembiasaan shalat dhuha setiap hari, shalat Dhuhur dan Jum'at secara berjamaah.

Kurikulum SD Plus Islamic Center yang dikembangkan adalah kurikulum secara integral ${ }^{7}$, yaitu antara pelajaran agama maupun umum, dimana kurikulum ini didesain pada setiap guru harus mengintegrasikan nilai-nilai Islami dalam kegiatan belajar mengajar (KBM). Tujuan ini agar setiap anak didik memiliki pemahaman yang lengkap dan shahih dalam setiap pelajaran yang diterima,

\footnotetext{
7 Pendidikan integralistik, merupakan model pendidikan yang diorientasikan pada komponenkomponen kehidupan yang meliputi: Pendidikan yang berorientasi pada Rabbaniyah [Ketuhanan], insaniyah [kemanusiaan] dan alamiyah [alam pada umumnya], sebagai suatu yang integralistik bagi perwujudan kehidupan yang baik dan untuk mewujudkan rahmatan lil 'alamin, serta pendidikan yang menggap manusia sebagai sebuah pribadi jasmani-rohani, intelektual, perasaan dan individual-sosial. Pendidikan integralistik diharapkan dapat menghasilkan manusia [peserta didik] yang memiliki integritas tinggi, yang dapat bersyukur dan menyatu dengan kehendak Tuhannya, menyatu dengan dirinya sendiri sehingga tidak memiliki kepribadian belah atau kepribadian mendua, menyatu dengan masyarakat sehingga dapat menghilangkan disintegrasi sosial, dan dapat menyatu dengan alam sehingga tidak membuat kerusakan, tetapi menjaga, memlihara dan memberdayakan serta mengoptimalkan potensi alam sesuai kebutuhan manusia. Dengan demikian, dapat dikatakan bahwa konsep pendidikan Islam adalah pendidikan yang bersumber dari konsep Ketuhanan [Teosentris], artinya pendidikan Islam harus berkembang dan dikembangkan berdasarkan teologi tersebut. Konsep kemanusiaan, artinya dengan konsep ini dapat dikembangnya antropologi dan sosiologi pendidikan Islam, dan konsep alam dapat dikembangkannya konsep pendidikan kosmologi dan ketiga konsep ini harus dikembangkan seimbang dan integratif. Lihat lebih lengkap dapat dilihat Fadjar, A. Malik., 1999, Reformasi Pendidikan Islam, Jakarta: Fajar Dunia
} 
maka nilai afeksi Islam mewarnai pada proses Kegiatan (K) Belajar (B) Mengajar (M) di semua mata pelajaran yang diberikan pada siswa ${ }^{8}$. Dari hasil pengamatan menunjukan bahwa implementasi dari konsep integrasi antara iman, ilmu dan amal terlihat nampak suasana Islam dalam kehidupan siswa dan guru di lingkungan sekolah mulai masuk hingga keluar sekolah.

Pada bidang studi atau mata pelajaran umum, nilai-nilai agama Islam dimasukkan dalam aktifitas pembejaran di kelas, sehingga penanaman konsep dapat diterima anak sejernih dan sejelas mungkin, serta dapat mencerna pula nilai-nilai Islami yang ditampilkan guru, baik dalam bentuk konsep, nilai maupun perbuatan. Demikian pula dalam bidang studi agama, pembelajaran dikelas dengan memasukkan nilai nyata sehari-hari yang lebih dipahami oleh siswa sehingga dapat menerimanya secara nyata dan utuh. Integrasi ini diharapkan terciptanya guru umum yang agamis dan guru agama yang sains.

Pada prakteknya kegiatan belajar mengajar dilakukan di kelas baik meteri pendidikan agama dan pendidikan umum adalah dengan menekankan pada: a) Menampilkan Tuhan sebagai sumber segala keilmuan, b) Islamisasi materi, c) Memberi syarah hadits, sirah, dan kisah baik di pembukaan, inti ataupun penutup, d) Tidak memisahkan makhluk dan khaliknya, e) Menampakan perilaku sopan santun dalam perkataan dan perbuatan. ${ }^{9}$

Bersamaan dengan itu, SD ini juga menawarkan keunggulan tertentu kepada masyarakat, yakni mendidik siswa berakhlakul karimah dan berprestasi akademik secara maksimal. Dari sini, SD Plus tampil dengan sejumlah konsep unggulan seperti jaminan mutu yang dirumuskan dalam dalam beberapa point berikut: Pertama, siswa dapat membaca al-Qur'an dengan baik, kedua siswa

\footnotetext{
8 Wawancara dengan Dra. Rahma Afiya Agustiyati, Kepala Sekolah SD Plus Islamic Centre

${ }^{9}$ Buku Panduan Sekolah Dasar Plus Islamic Centre Manado, h. 7
}

dapat mengahafal Juz 'Amma dan Al-Qur'an. Keunggulan kedua ini menjadi modal untuk berdakwah, seperti siswa dapat menjadi imam shalat di Masjid dan lain-lain. Ketiga siswa dapat menguasai bahasa arab dan Inggris, keempat dapat menguasai do'a sehari-hari dan amalan Islami lainnya.

Kurikulum selain Pendidikan Agama Islam (PAI), diterapkan juga beberapa pelajaran/ materi yang bernuansa agama Islam seperti: Bahasa Arab, Kaligrafi, Baca Iqro, Tahfidz, Do'a sehari-hari, Praktek Ibadah. Pelajaran Bahasa Arab diberikan dari kelas I sampai Kelas IV, Untuk Baca Iqro diberikan di kelas I dan II sedangkan kelas III sampai kelas VI membaca al-Qur'an. Dari kurikulum pendidikan agama yang dikembangkan di atas, diharapkan melahirkan output kompetensi lulusan SD Plus Islamic Center Manado:

a. Shalat tanpa disuruh

b. Berpakaian secara Islami dalam kehidupan sehari-hari di lingkungan keluarga, masyarakat dan sekolah

c. Sopan santun dalam bertutur kata dan bersikap: 1) Salam bila bertemu sesama Islam, 2) Menebar senyum terhadap orang lain, 3) Meminta izin bila ada keperluan

d. Tilawah al-Qur'an setiap hari tanpa disuruh

e. Pemikir kritis dan pemecah permasalahan

f. Belajar sepanjang hayat: 1) Belajar mandiri tanpa disuruh, 2) Memiliki ketrampilan belajar, 3) Belajar tanpa batas waktu, 4) Siap masuk ke jenjang pendidikan yang lebih tinggi.

g. Pekerja kelompok:1) Menerima perbedaan, 2) Terlibat aktif dalam kelompok, 3) Menghargai keputusan kelompok

h. Komunikator: 1) Berkomunikasi dalam Bahasa Indonesia yang baik dan benar, 2) Berkomunikasi dalam bahasa Inggeris/ Arab lisan dan tulisan dalam kalimat sederhana dalam kenteks keseharian 
i. Berpola hidup yang sehat dengan berkebiasaan baik dalam kebersihan, makan, tidur, puasa, olahraga

j. Peduli lingkungan; alam, sosial dan budaya

k. Penikmat dan menghargai karya seni Islami

\section{Rekruitmen Pimpinan, Pendidik dan Peserta Didik.}

Sebagai sekolah Plus yang memiliki nilai plus/tambah atau keunggulan tertentu yang mungkin tidak dimiliki oleh sekolah-sekolah lain, seperti dalam hal kurikulum pendidikan, sarana prasarana, visi dan misi. Sekolah juga menawarkan sejumlah nilai keunggulan dalam hal sistem rekruitmen pimpinan, tenaga pendidik, dan peserta didik. Sistem rekruitmen ini dilakukan secara selektif.

Sistem rekruitmen pimpinan dan tenaga pendidik dilakukan penilaian oleh yayasan yang selanjutnya diputuskan melalui surat keputusan Yayasan. Diantara kualifikasi pimpinan/kepala sekolah secara umum adalah lulusan sarjana pendidikan S1, memiliki jiwa leadership, memiliki integritas moral yang tinggi, mampu menjalankan roda lembaga. Sedangkan secara khusus harus mendapatkan pertimbangan dari pihak yayasan, memiliki visi dalam meningkatkan sekolah dan siap bekerja full days.

Sedangkan Sistem rekruitmen pendidik dilakukan seleksi ketat mulai dari administarasi, wawancara, psikotest dan mikroteaching. Adapun kriteria kualifikasinya sebagai berikut: a) memiliki pengalaman mengajar, b) Sarjana S1 dalam bidang pendidikan, c) dapat membaca al-Qur'an, dapat berbicara bahasa Inggris dan Arab (minimal pasif), d) memakai busana muslimah (bagi guru Wanita). Sementara itu, dalam hal rekruitmen siswa juga dilakukan secara selektif, diantara persyaratan bagi siswa yang masuk SD Plus Islamic Center dilakukan melalu tes, baik secara lisan maupun tertulis; bagi siswa yang berasal dari TK Islamic Centre mendapatkan prioritas tersendiri, sedangkan di luar itu harus menjalani tes. Karena keterbatsan sarana dan jumlah SDM, pihak sekolah dari awal berdiri hanya menerima 2 lokal dengan rincian jumlah siswa 30 siswa per kelas pada awalnya. Diantara persyaratan masuk adalah: Persyaratan utama: Beragama Islam, atas kemauan sendiri yang ditunjang dengan kemauan orang tua, memilki Ijazah/STTB dari Taman KanakKanak, berkemauan melaksanakan tata tertib. Sementara persyaratan lainya adalah: berumur $6-8$ tahun, dapat membaca huruf al-Qur'an, sekurang-kurangnyaa berkemauan untuk tahu membaca huruf al-Qur'an, lulus testing saringan penerimaan yang diadakan apabila siswa pelamar melebihi dari renecanaa penerimaan dan Orangtua bersedia memenuhi beban biaya belajar yang ditentukan sekolah.

\section{Pengembangan Inovasi Pembelajaran}

Beberapa inovasi pengembanagan pembelajaran di SD Plus Islamic Center sebagaimana disebutkan dalam proses pembelajaran (KBM) dilakukan secara integral maka dalam proses KBM selalu memasukan ketiga aspek tersebut. Dalam prakteknya setiap kegiatan pembelajaran sebelum masuk kelas, siswa berkumpul berbaris untuk menghafal/ murajaah Juz 'Amma dan Al-Qur'an. Kemudian setiap mulai dan berkahir proses KBM juga selalu dilakukan membaca do'a, proses pembiasaan ini selalu ditekankan dalam setiap kegaiatan belajar mengajar.

Salah satu yang menjadi perhatian sekolah dalam mengembangkan keberhasilan pendidikan anak, selalu menekankan adanya komunikasi dengan orangtua terkait dengan perkembangan anak-didik baik secara langsung maupun tidak lansung seperti melalui Buku penghubung siswa.

Sekolah misalnya dalam mengembangkan pola komunikasi yang baik dalam memajukan keberhasilan siswa, sebagaimana para ahli menyebutkan ada tiga peran penting dalam keberhasilan pendidikan yaitu: keluarga, sekolah dan masyarakat. Tiga peran ini, 
satu sisi memang telah menyederhanakan, memudahkan pola pembahasan, pemantauan dan evaluasi pendidikan. Namun disisi lain dapat memungkinkan adanya sikap parsial terhadap tiga pusat pendidikan tersebut yaitu mempunyai persepsi, visi dan orientasi yang sama. Sekolah berusaha mendidik siswanya untuk gemar berdo'a dan beribadah, tetapi justeru keluarga tidak mencerminkan situasi yang seharunya. Akibatnya anak mengalami pada dua kondisi yang berbeda dan dapat mengarah kepada perkembangan jiwa yang tidak utuh. ${ }^{10}$

Didasari hal itu, SD Plus Islamic Center menerapkan program buku penghubung dan Informasi Guru dan Orang tua (IPOG) yang pemantau aktifitas pendidikan anak yang akan dilakukangurudanorangtuamelalui pengisisan buku kegiatan anak haria maupun mingguan. Dalam buku penghubung ini minimal tiga tujuan dari program IPG: pertama, memberikan informasi kepada guru dan orangtua mengenai sikap perilaku yang perlu ditanamkan kepada anaka, kedua: menjalin kerjasama anatar pihak sekolah dengan orangtua dalam hal memantau sikap dan perilaku anak didik sehari-hari, dan ketiga, memantau kemampuan anak didik dalam menumbuh kembangkan sikap dan perilaku yang baik dan islami sebag bagian yang tidak terpisahkan dari tujuan pendidikan yang dicanagkan oleh SD Plus ini.

Buku penghubung juga diharapkan dapat memudahkan kontrol dan komunikasi antar guru dan orang tua. Diantara komunikasi yang diterapkan itu melalui beberapa cara seperti: a) setiap menjelang pulang dari sekolah, guru memberi informasi kepada orang tua tentang kegiatan sisiwa selama di sekolah dan tugas yang harus di kerjakan, b) orangtua setiap hari bisa mengetahui kegiatan anak selama di sekolah dengan memeriksa buku penghubungnya. Tanda tangan orangtua telah memeriksa penghubung tersebut, c) setiap pagi saat masuk, semua siswa langsung

${ }^{10}$ Wawancara dengan Dra. Rahma Afiya Agustiyati, Kepala Sekolah SD Plus Islamic Centre mengumpulkan buku penghubung di atas meja guru dan guru dapat memerikas kembali tanggal atau informasi dari orang tua, d) setiap minggu orang tua juga menginformasikan ke sekolah tentang aktifitas anak selama di rumah dengan mengisi tabel aktifitas di rumah, yaitu dengan penliaian kata-kata: selalu, sering atau jarang.

\section{Penguatan Jaringan Kelembagaan}

Pendidikan merupakan tugas dan tanggung jawab orang tua, sekolah dan masyarakat. Orang tua sebagai pengguna hasil pendidikan memiliki tugas yang sama dalam mendidik anak. Hubungan para orangtua murid dengan pihak sekolah bersifat mutualistik dan bersama-sama mewujudkan kerjasama yang produktif dan saling pengertian. Melalui Komite Sekolah, orang tua murid dapat memainkan peran dalam membantu melancarkan proses pendidikan, memberikan masukan, saran, tanggapan, gagasan dan melakukan evaluasi terhadap jalannya proses pendidikan. Komite sekolah merupakan bagian integral dari struktur lembaga pendidikan.

Untuk memperkuat kelembagaan dan memperluas pengembangan mutu pendidikan, SD Plus Islamic Center Manado terus menjalin kerjasama dengan berbagai pihak, baik dalam kontek pendidikan maupun non pendidikan. Dalam kontek pendidikan misalnya, selalu menjalin kerjasama dengan pihak Dinas pendidikan baik Kota maupun Propinsi, demikian juga dalam hal pendidikan agama tetap menjalin komunikasi dengan pihak Kementerian Agama kota maupun Propinsi. Dengan lembaga sekolah lain pun terus menjalin komunikasi baik dalam hal tukar menukar wawasan keilmuan dengan berbagi pengalaman yang tidak hanya dilakukan dengan lembaga milik Islam saja, tetapi juga dengan lembaga non muslim seperti dengan lembaga Kanisius, Santa Maria, De Borah dan lainnya. Dengan lembaga pendidikan Islam tak terkucuali terus menjalin komunikasi seperti SD Muhammadiayah, SD al-Khairat, SD Yapim 
dan di luar Manando seperti dengan melakukan kunjungan studi banding dengan Perguruan al-Azhar, Sekolah Terpadu dan sebagainya. Untuk mempromosikan lembaga ini selain dengan menjalin silaturrahmi secara berkala dengan orang tua siswa, juga melakukan sosialisasi kepada masyarakat luar dengan cara memberikan informasi kepada warga muslim yang bekerja di instansi pemerintahan maupun swasta.

\section{Pendidikan Islam Alternatif; Peluang dan Tantangan}

Munculnya pendidikan Islam alternatif merupakan perubahan atas lembaga pendidikan yang berkembang selama ini, yaitu perubahan atas kegagalan yang dilakukan oleh sekolah umum dan lembaga pendidikan Islam dalam memadukan ilmu umum dan ilmu agama. Mereka tidak puas terhadap kurikulum pendidikan (model sekolah) yang dikembangkan oleh kementerian Pendidikan Nasional maupun y model yang dikembangkan oleh Kementerian Agama (Madrasah).

Hadirnya model sekolah ini (plus, terpadu dan sejenisnya) dalam prakteknya berusaha melakukan pengembangan kurikulum dengan cara memadukan kurikulum Kementerian Pendidikan Nasional seperti mata pelajaran Matematika, IPA, IPS, bahasa Inggris, bahasa Indonesia, dan lain-lain, serta kurikulum pendidikan agama Islam yang ada di Kementerian Agama dan ditambah dengan kurikulum yang dikembangkan sekolah tersendiri (yayasan).

Di sisi lain, kesadaran masyarakat akan pentingnya pendidikan bagi masa depan generasi mendatang semakin meningkat. Kesadaran tersebut tidak hanya berkembangng di kalangan masyarakat perkotaan lapisan menengah atas, tetapi sudah mulai hampir merata di kalangan masyarakat pedesaaan lapisan bawah. Kesadaran tersebut telah menembus batas-batas sosial, kultural dan keagamaan baik di kalangan santri, priyayi maupun abangan-mengambil istilah kategori Geerts.

Masyarakat menyadari bahwa tanpa bekal pendidikan yang memadai, anak-anak mereka akan kalah dalam persaingan memasuki lapangan kerja yang pada gilirannya secara sosial akan terpinggirkan. Secara kultural masyarakat muslim masih memandang kebutuhan akan pendidikan bukan terbatas penguasaan terhadap aspek intelektual dan ketrampilan lebih dari itu pendidikan harus menjadi tempat sosialisasi, penanaman nilai-nilai keimanan,ketakwaan, moralitasdannilai-nilailuhur budaya. Keimanan, ketakwaan dan moralitas harus mendasari penyelenggaraan, proses pembelajaran serta keluaran pendidikan. Hal ini sejalan dengan tujuan pendidikan nasional yang tercantum dalam UU No. 20 tahun 2003 tentang Sistem Pendidikan Nasional yang berbunyi "Pendidikan adalah usaha sadar dan terencana untuk mewujudkan suasana belajar dan proses pembelajaran agar peserta didik secara aktif mengembangkan potensi dirinya untuk memiliki kekuatan spiritual keagamaan, pengendalian diri, kepribadian, kecerdasan, akhlak mulia, serta keterampilan yang diperlukan dirinya, masyarakat, bangsa dan negara. Berdasarkan definisi di atas, terdapat (tiga) pokok pikiran utama yang terkandung di dalamnya, yaitu: (1) usaha sadar dan terencana; (2) mewujudkan suasana belajar dan proses pembelajaran agar peserta didik aktif mengembangkan potensi dirinya; dan (3) memiliki kekuatan spiritual keagamaan, pengendalian diri, kepribadian, kecerdasan, akhlak mulia, serta keterampilan yang diperlukan dirinya, masyarakat, bangsa dan negara.

Munculnya lembaga pendidikan agama yang menjadi pilihan atau alternatif masyarakat Islam Kota Manado yang paling utama adalah sebagai bentuk keprihatinan dari kalangan muslim tersendiri. Dari lembaga pendidikan muslim yang ada --misal Muhammadiyah, Al-Khairat, bila dibandingkan dengan sekolah negeri dan sekolah non muslim jauh 
ketinggalan, baik dari segi kualitas maupun kuantitas. Hal ini menjadi tantangan dan peluang tersendiri bagi masyarakat muslim Manado.

Hadirnya Sekolah Dasar Plus Islamic Center di Manado dan mendapatkan respon poisitif di Masyarakat, setidaknya dapat dilihat dalam beberapa hal diantaranya: Pertama, Tumbuhnya semangat di kalangan muslim menengah Manado mendapatkan pendidikan Islam yang berkualitas bagi anak-anak mereka. Keinginan mereka pada dasarnya adalah pendidikan umum Islam yang berkualitas tinggi, dimana peserta didik tidak hanya bergumul dengan ilmu-ilmu yang penting untuk kehidupan masa kini di dunia ini, tertapi juga ilmu-ilmu dan amal Islam. Atau sebaliknya, pendidikan berbasis agama-dalam hal ini Madrasah dan pesantren-tetapi unggul juga dalam ilmu-ilmu umum ${ }^{11}$.

Kedua, adanya ekspektasi masyarakat muslimManandountukmendapatkankeilmuan secara integral yaitu penguasaan iptek dengan imtak dalam kurikulum pembelajaran mereka. Dengan kurikulum integraif tersebut para siswa dapat berkompetensi dengan sekolah umum maupun agama. Hal ini sebagai bentuk kritik terhadap sistem pendidikan pada umumnya yang hanya menitikberatkan pada penguasaan iptek tanpa dibarengi dengan landasan imtak, tetapi juga kritik terhadap lembaga madrasah yang lebih berorientasi kepada penguasaan imtak namun lemah dalam penguasaan iptek.

Ketiga, dalam rangka membangun image yang selama ini ummat Islam belum mampu menyelenggarakan pendidikan yang bermutu dan menjadi pilihan ummat Islam, yang kompetitif mengungguli sekolah-sekolah non muslim. Banyaknyanya sekolah favorit yang diselenggarakan lembaga non muslim, menjadi pilihan tersendiri bagi sebagian masyarakat muslim. Akibatnya sebagian muslim yang menyekolahkan anaknya ke lembaga non muslim lebih melihat pada kualitas pendidikan

\footnotetext{
${ }^{11}$ Jajat Burhanuddin, dkk., loc. cit
}

umum dan mengabaikan faktor agama, tidak sedikit anak-anak mereka mendapatkan pelajaran agama non muslim dan mengikuti kegiatan keagamaan. Dengan gambaran ini, munculnya sekolah Islam yang menjadi pilihan merupakan tantangan tersendiri bagi penyelenggara pendidikan, bila penyelenggara pendidikan Islam dapat membuktikan dan menjawab akan kebutuhan masyarakat muslim maka dengan sendirinya akan mendapatkan dukungan dari masyarakat muslim.

Bila dilihat pola pengembangan pendidikan yang dikembangkan SD Plus Islamic center dan sekolah Islam unggulan lainnya, seperti yang ditulis Azra ada semacam "Santrinisasi"12. Pola santrinisasi itu terjadi melalui dua cara: pertama; murid atau siswa dari sekolah-sekolah itu umunya telah mengalami "re -islamisasi". Hal ini terjadi karena disamping mempelajari ilmu-ilmu umum, mereka mempelajari ilmuilmu Islam, mulai dari bagaimana membaca al-Qur'an, melaksanakan salat dengan tepat dan benar, hingga ajaran-ajaran Islam yang sangat fundamental. Kedua, murid atau siswa sekolah itu selanjutnya membawa Islam yang mereka pelajarai di sekolah ke rumah, dalam banyak kasus mereka bahkan mengajarkan kepada orangtua mereka yang acapkali hanya mengetahui sedikit tentang Islam, mislanya, tentang bagaimana caranya shalat, membaca al-Qur'an, bagaimana cara melaksanakan ibadah-ibadah Islam lainnya. Umumnya orangtua merasa malu akibat ketidaktahuan mereka mengenai ajaran dan praktik Islam tertentu. Akibatnya agar tidak mengecewakan sang anak mereka mulai mempelajari Islam, baik secara sendiri maupun dengan cara mengundang guru prifat untuk mengajarkan kepada mereka tentang Islam. Hal ini juga seperti apa yang dialami beberapa orang tua.

Pilihan masyarakat untuk memperoleh sekolah unggul adalah dambaan akan masa depan anaknya,. Orang tua menyekolahkan

${ }^{12}$ Azyumardi Azra. 2000. Penddikan Islam: Tradisi dan Modernisasi Menuju Milenium Baru. Jakarta: PT Logos Wacana Ilmu, h. 80 
di sekolah Islam unggulan dan bermutu karena orang tua ingin memberikan prospek yang pasti bagi anak-anak mereka untuk melanjutkan pendidikan hingga pendidikan lebih tinggi, dapat bersaing dengan sekolah-sekolah misionaris. Mereka ingin memeproleh pandangan dan pemahaman yang komprehensip tentang Islam. Banyak orangtua Muslim yang mengetahui sedikit tentang Islam kini boleh merasa yakin bahwa anak mereka akan mendapatkan pengetahuan dan pemahanan yang lebih luas tentang ajaran Islam. Lebih dari itu anak-mereka diajarkan tentang bagaimana mempraktikkan ajaranjaran Islam dalam kehidupan sehari-hari. Misalnya mereka tidak hanya mempraktikkan kegiatan dengan dimulai membaca do'a, dan salat wajib lima waktu, tetapi juga diajarkan untuk memimpin shalat itu sendiri atau menjadi imam shalat. Selain itu orang tua merasa nyaman berada di lingkungan pendidikan Islam di bandingkan lembaga umum atau lebih-lebih di lembaga misionaris.

Otonomi Daerah membawa pengaruh tersendiri bagi perkembangan pendidikan Islam, apalagi secara geopolitik Kota Manado penduduknya bukan mayoritas muslim, misalnya beberapa kebijakan Pemerintah Daerah dianggap kurang berpihak terhadap lembaga pendidikan minoritas. Perlakuan ini sangat dirasakan bagi Sekolah-Sekolah Islam (karena memang dibawah binaan Dinas Pendidikan), Pemda lebih mengutamakan lembaga -lembaga pendidikan yang dimiliki mayoritas bila dibandingkan dengan lembaga pendidikan yang dimilki minoritas. Suasana demikian menjadi tantangan tersendiri bagi sekolah-sekolah muslim.

Sekolah alternatif memang merupakan pilihan bagi masyarakat yang sadar akan pentingnya pendidikan yang bermutu, tetapi kesempatan mendapatkan pendidikan agama yang berkualitas bagi semua kalangan baik ekonomi lemah, menengah dan atas, belum semuanya terpenuhi. Karena sekolah unggul atau plus yang ada membutuhkan biaya yang besar, bagi mereka yang kaya saja dapat menyekolahkan anak-anak mereka ke Sekolah Unggulan. Sedangkan yang golongan ekonomi ke bawah masih perlu adanya campur tangan pemerintah.

SD Plus Islamic Center merupakan salah satu kebanggan tersendiri dan menjadi alternatif atau pilihan pendidikan Islam bagi masyarakat muslim Manado, sekolah ini menjadi Sekolah Unggulan, karena itu hadirnya lembaga pendidikan Islam ini sebagaimana yang disebutkan Azra-- tidak hanya berdampak pada perbaikan lembaga pendidikan Islam, tetapi juga pada pada proses santrinisasi masyarakat muslim.

Kedepan, pendidikan Islam alternatif/ unggul/plus/terpadu dan sejenisnya akan banyak tumbuh berkembang dan menjadi pilihan masyarakat muslim untuk menyekolahkan anaknya, selama pendidikan Islam ini selalu menjaga mutu dan kualitas baik manajeman, tenaga pendidik, kurikulum, sarana dan parasarana dan mampu bersaing secara kompetitif dalam mengahadapi globalisasi. Karena tanpa ini, lembaga pendidikan Islam akan dengan sendirinya ditinggalkan oleh masyarakat sebagai penggunanya.[]

\section{PENUTUP}

\section{Kesimpulan}

1. SD Plus Islamic Centre Manado memberikan pelayanan pendidikan agama kalangan muslim lapisan menengah; Mereka melihat sekolah, madrasah yang ada belum sepenuhnya memenuhi harapan mereka. Penyelenggaraan pendidikan SD PIC dikelola secara "Islami" dengan menerapkan prinsip-prinsip pendidikan modern (kurikulum, proses pembelajaran, sarana, budaya sekolah dan jaringan pendidikan yang dibangun.

2. Hadirnya lembaga pendidikan Islam alternatif yang menawarkan berbagai 
keunggulan dan kompetitif merupakan harapan dan cita-cita ummat Islam. Pilihan masyarakat muslim Manado yang menjadikan pendidikan Islam alternatif, karena didasari beberapa faktor yaitu: pertama, sebagai bentuk quaranti terhadap pembinaan ideologi/akidah sekaligus menawarkan pendidikan yang berkualitas. Kedua: mengembangkan kurikulum berbasis agama (IMTAK) dan dan umum (IPTEK) dengan mengintegrasikan NilaiNilai Keislaman dalam setiap proses setiap Kegiatan Belajar Mengajar (KBM), ketiga dapat berkompetisi dalam memasuki perkembangan dunia yang mengglobal.

\section{Rekomendasi}

1. Untuk meningkatkan akses atau kesempatan medapatkan pendidikan agama yang universal, perlunya dipikirkan format sekolah agama alternatif bagi semua kalangan baik bagi masyarakat ekonomi lemah, menengah dan atas.

2. untuk kemenag; mendorong pengembangan mutu pendidikan ini melalui peningkatan kompetensi guru, inovasi pembelajaran, bantaun sarana belajar,

3. Ke depan lembaga pendidikan/sekolah model yang dikembangkan lembaga ini akan semakin banyak sejalan dengan semakin meningkatnya minat masyarakat akan lembaga pendidikan yang bermutu. Karennya lembaga pendidikan terus melakukan perbaikan dalam hal mutu pendidikan, inovasi pembelajaran, sarana dan prasarana pembelajaran.

4. Sebagai bagian dari sitem pendidikan nasional, pendidikan model SD Plus Islamic Centre dan lembaga lainnya tetap memperhatikan tuntutan perlunya penanaman nilai-nilai kebangsaan, pluralitas dan toleransi serta budaya kecerdasan sebagai salah satu misi utama lembaga pendidikan.

\section{SUMBER BACAAN}

Arifi, Zaenal. (2012): Pengembangan Manajemen Mutu Kurikulum Pendidikan Islam. Yogyakarta, DIVA Press.

Azra, Azyumardi (2000): Penddikan Islam: Tradisi dan Modernisasi Menuju Milenium Baru. Jakarta, PT Logos Wacana Ilmu

A.E. Woolfolk. (1993): Educational Psychology . Needham Heights: Allyn \& Bacon

Burhanuddin, Jajat dkk. (2006): Mencetak Muslim Modern: Peta Pendidikan Islam Indonesia. Jakarta, PT RajaGrafindo Press.

Bunga Rampai kajian Pendidikan Nasional. (1998): Pendidikan Alternatif sebagai proses pemanusiaan. Jakarta: Depdiknas

Buku Panduan Sekolah Dasar Plus Islamic Centre Manado Sulawesi Utara

Chan, Sam M. dan T. Sam, Tuti T. (2005): Analisis SWOT: Kebijakan Pendidikan Era Otonomi Daerah. Jakarta, PT RajaGrafindo Persada.

Fadjar, A. Malik.. (1999): Reformasi Pendidikan Islam. Jakarta, Fajar Dunia

Dewey, Jhon. (2004): Experience and Education.. Jakarta, Teraju Mizan

Johar. (2008): Kurikulum yang mencerdaskan. Visi 2030 dan Pendidikan Alternatif . Jakarta, Penerbit Buku Kompas

Miarso. Yusufhadi. (1999): Pendidikan Alternatif Sebuah Agenda Reformasi. Jakarta, Jurusan Teknologi Pendidikan UNJ

Peraturan pemerintah No 55 Tahun 2007 tentang Pendidikan Agama dan Pendidikan Keagamaan

Tilaar, H.A.R. (1998): Beberapa Agenda reformasi Pendidikan Nasional Dalam Perspektif Abad 21. Magealang, Penerbit Tera Indonesia

Undang-Undang RI No. 20 Tahun 2003 tentang Sistem Pendidikan Nasional (Sisdiknas) 